http://dx.doi.org/10.12775/szhf.2018.022

Karol Michalski

Uniwersytet Śląski, Katowice, Polska

E-MAIL: K.MICHALSKI@AON.AT

\title{
Poszukiwanie sensu według logoterapii i analizy egzystencji Viktora E. Frankla
}

W wykładzie Czym jest myślenie Heidegger powiedział: „Każdy myśliciel myśli tylko jedną jedyną rzecz" ${ }^{1}$. Myślenie o jednym nie oznacza, że nie myśli się o niczym innym, lecz wszystko, o czym się myśli, sprowadza się do jednej rzeczy. Myślenie jednego nie jest też powtarzaniem jednego i tego samego. Myśliciel nie myśli tak samo o tym samym, tylko w różny sposób o tym samym. Wyróżniona rzecz jest środkiem myślenia, z którego myśliciel wychodzi i do którego powraca.

Centralną rzeczą w logoterapeutycznym myśleniu Frankla jest sens. Sens w logoterapii przynależy do życia. Życie ma zawsze sens i nie traci go w żadnych warunkach i okolicznościach. Życie samo w sobie nie może stać się bezsensowne. Człowiek może postrzegać i przeżywać swoje życie jako pozbawione sensu. Frankl rozjaśnia sens życia w myśleniu filozoficznym i myśleniu psychoterapeutycznym. Poszukuje warunków możliwości sensownego życia w egzystencjalnych analizach i uzasadnia logo-teorię w logoterapeutycznej praxis $^{2}$.

\footnotetext{
${ }^{1}$ M. Heidegger, Was heißt Denken, Max Niemeyer Verlag, Tübingen 1952, s. 20.

2 „Nasza logoteoria może być nie tylko empirycznie, ale też praktycznie potwierdzona. To, czego prawie nie ważymy się wypowiedzieć, jest przez naszych pacjentów zamieniane w czyn. Nie my ich pouczamy, lecz możemy się od nich uczyć. [...] Istnieją chorzy, którzy pomagają
} 
Pytanie o sens jest dla człowieka nieuniknione. Człowiek jest zdany na rozumienie swojego bycia w świecie. Czym jesteśmy jako ludzie, rozumiemy poprzez to, że stawiamy pytanie o sens naszej egzystencji. Dopóki człowiekowi dobrze się wiedzie, łatwo przychodzi mu powiedzieć życiu „tak”. Kierunek życia jest prawidłowy i jego sens jest nie do zakwestionowania. Sens egzystencji zostaje przeważnie postawiony pod znakiem zapytania, kiedy pojawia się cierpienie. $\mathrm{W}$ cierpieniu $\mathrm{z}$ trudem przychodzi przyjęcie życia jako wyrazu przeżytej sensowności. W logoterapii Frankl podejmuje zmaganie $\mathrm{z}$ „cierpieniem na bezsens życia”, które jest cierpieniem dzisiejszych czasów. W analizie egzystencji Frankl poszukuje możliwości sensownego życia. „W tym sensie analiza egzystencji jest terapią ' $w$ tym, co zdrowe"'4. Analiza egzystencji pokazuje, jak zachować „zdrowe”, sensowne egzystowanie.

Istnieją trzy Wiedeńskie Szkoły Psychoterapii ${ }^{5}$. Pierwsza o nazwie „psychoanaliza" została założona przez Sigmunda Freuda (1856-1939), druga „psychologia indywidualna” przez Alfreda Adlera (1870-1937), trzecia zaś to „logoterapia” założona przez Viktora E. Frankla (1905-1997). Wszyscy trzej założyciele znali się, wymieniali ze sobą myśli i uzupełniali się wzajemnie wynikami swoich badań.

Sigmund Freud szukał przyczyny symptomów neurotycznych w raczej pruderyjnej społeczności swoich czasów i odkrył nieświadome życie duszy człowieka. Rozwinął swoją naukę o wypieraniu (Verdrängungslehre), w której ukryte pożądania seksualne i doniosłe traumy dziecięce zostają wyparte z świadomości w sferę nieświadomą i z biegem czasu, w późniejszym okresie życia, mogą okazać się przeżyciami wywołującymi neurotyczne zaburzenia.

Alfred Adler sięgnął w swoich badaniach, nie tak jak Freud do tego, co psychiczne, lecz do tego, co biologiczne, to znaczy, do niedostatków organów cielesnych (Organminderwärtigkeiten), jak na przykład, niski wzrost, krzywy nos, grube nogi i tym podobne. Pokazuje powiązanie niskiej wartości organów cielesnych z życiowym przeznaczeniem. Odkrył, że organiczne niedostatki mogą wywołać poczucie niskiej wartości, które dąży do kompensacji

zdrowym w ich zmaganiu o sens." V. E. Frankl, Die Sinnfrage in der Psychotherapie, Piper Verlag, München 1996, s. 64.

${ }^{3}$ V. E. Frankl, Das Leiden am sinnlosen Leben. Psychotherapie für heute, Kreuz Verlag, Freiburg im Breisgau 2015.

${ }^{4}$ V. E. Frankl, Logotherapie und Existenzanalyse. Texte aus sechs Jahrzehnten, Beltz Verlag, Weinheim und Basel 2010, s. 100.

${ }^{5}$ E. Lukas, Der Schlüssel zu einem sinnvollen Leben. Die Höhenpsychologie Viktor E. Frankls, Kösel Verlag, München 2011, s. 14. 
i z czasem zostaje chorobliwie nadkompensowane w postaci wygórowanego dążenia do ważności lub pędu do władzy.

Viktor Frankl nie miał wątpliwości co do przyczyn patologicznych symptomów opisywanych w psychoanalizie i psychologii indywidualnej, lecz powątpiewał w to, że człowiek wystawiony na pastwę popędów i kompleksów nie jest panem w swoim własnym domu. W poszukiwaniu fundamentalnych sił leczniczych duszy, które mogłyby, w razie konieczności, oprzeć się niektórym popędom i pogodzić się z organicznymi niedostatkami, Frankl odkrył duchowy wymiar człowieka, przy czym przez duchowość nie rozumie tu zdolności logicznych ani intelektu. Dla Frankla duchowość to dosłownie humanitas jako: wolność wyboru i podejmowania decyzji, odpowiedzialność, siła ducha, sumienie, wrażliwość na wartości, wiara w sens, wola sensu, osobista godność. Frankla logoterapia jest fascynującą próbą przezwyciężania kryzysu sensu, poprzez odkrywanie i pobudzanie możliwości duchowych egzystencji i pokazywanie możliwości sensownego wypełnienia życia przez urzeczywistnienie wartości.

\section{Samotranscendowanie jako droga do sensu}

Logoterapia zmaga się z nerwicami, które wyrażają się w zaburzeniach psychosomatycznych i w kryzysie sensu. Logoterapia potrzebuje analizy egzystencji, która poszukuje, neutralnej wobec zdrowia i choroby, przestrzeni w człowieku, z której można by się przeciwstawić temu, co chore i budować sens. „W tej przestrzeni analiza egzystencji odkrywa nienaruszone i nienaruszalne człowieczeństwo" ${ }^{\prime}$. Przestrzeń tego, co istotnie ludzkie, wykracza poza ulegający degradacji, „mechanizm psychofizyczny.” „Analiza egzystencji rozszerza swoją analizę na całość człowieka, która jest nie tylko psychofizyczno-organiczna, lecz także duchowo-osobowa"7. To, co duchowe i osobowe w człowieku, w przeciwieństwie do psychophysikum, jest w logoterapii i analizie egzystencji rozumiane jako wyższy wymiar, którego pozbawiona jest tak zwana psychologia głębi.

\footnotetext{
${ }^{6}$ V. E. Frankl, Logotherapie und Existenzanalyse, s. 86.

7 Tamże.
} 
Gdzie jest ta interesująca terapeutycznie psychologia, która uwzględniałaby w swojej koncepcji wyższe warstwy ludzkiej egzystencji i w tym sensie, a także w przeciwieństwie do określenia psychologia głębi, zasługiwałaby na miano psychologii wyżyn?

Przeciwieństwem psychologii głębi nie jest „psychologia powierzchni”, lecz psychologia wyżyn. Psychologia wyżyn nie wznosi się na „wyższy poziom” niż psychologia głębi. Freud był wystarczająco genialny, by znać miejsce psychonalizy, nazywanej psychologią głębi, gdy pisał do Ludwiga Binswangera: „Zawsze przebywałem tylko na parterze i w suterenie budynku" 9 . Jeżeli psychologia głębi zeszła do niższych partii domu, czyli nieświadomych i popędowych pokładów psychiki, to nie znaczy, że psychologia wyżyn zajęła wyższe piętra domu, wyżyny psychiki. Psychologia wyżyn odkryła serce domu, którym jest duchowy obszar ludzkiego bycia. „Psychologia wyżyn chce być psychoterapią wychodzącą od strony tego, co duchowe i w tym sensie wie o 'wyższym' wymiarze bycia ludzkiego"10. Psychologia wyżyn obejmuje całą ludzką egzystencję, w jej głębi i w jej wysokości. „Tak więc byłaby ona właściwą psychologią głębi, kiedy schodzi ona nie tylko do nieświadomych popędów, lecz także do nieświadomej duchowości" ${ }^{11}$. Duch zamieszkuje nie tylko to, co świadome, lecz także to, co nieświadome. Duch prowadzi ukryte życie. W tym, co nieświadome, oprócz popędów i kompleksów, kryją się duchowe siły, kierujące świadomym życiem człowieka. To, co nieświadome, kryje również ciemną stronę ducha. Ze świadomości wypierane są duchowe konflikty i urazy, które mogą obudzić się w postaci nerwic. „Freud powiedział, że ludzkość wie, że ma ducha, a on musiał jej pokazać, że ma popędy"12. Dzisiaj trzeba przypomnieć człowiekowi, że ma ducha. Trzeba mu pokazać, że jest istotą duchową, która może wstąpić na drogę sensu przez transcendowanie tego, co psychosomatyczne.

Logoterapię odróżniają od psychoanalizy i psychologii indywidualnej nie tylko „wyższe warstwy ludzkiej egzystencji”, lecz przynależący do nich sens. Przebiegi popędowe lub kompensacje kompleksu niższości jako wewnętrzne mechanizmy i procesy psychiczne „nie mogą tworzyć sensu całego ludzkiego

8 „Zentralblatt für Psychotherapie und Ihre Grenzgebiete einschließlich der medizinischen Psychologie und psychischen Hygiene“, Bd. 10, 3. Heft, Verlag von S. Hirzel, Leipzig 1938.

${ }_{9}^{9}$ L. Binswanger, Erinnerungen an Sigmund Freud, Francke Verlag, Bern 1956, s. 115.

${ }^{10}$ V. E. Frankl, Logotherapie und Existenzanalyse, s. 86.

11 Tamże.

12 Tamże, s. 87. 
bycia"13. Życie psychiczne, świadome czy nieświadome, nie może być wszystkim, na czym człowiek opiera sens swojego bycia.

Ludzkiemu byciu chodzi o wiele więcej niż o jakiekolwiek wewnętrzne stany; ponieważ bycie człowiekiem wskazuje zawsze ponad siebie samo, na coś, czym nie jest ono samo, lepiej powiedziawszy, na coś albo na kogoś, mianowcie na sens, którego wypetnienie oferuje się człowiekowi ${ }^{14}$.

Samolot nie przestaje być samolotem, kiedy porusza się tylko po ziemi. Może, a nawet musi poruszać się po ziemi. Tym, czym samolot jest w istocie, okazuje się dopiero, kiedy wzniesie się w przestrzeń powietrzną. „Analogicznie człowiek rozpoczyna zachowywać się jako człowiek, kiedy może wystąpić z płaszczyzny psychofizyczno-organicznej faktyczności i stanąć naprzeciw siebie"15. Egzystowanie jest właściwie transcendowaniem siebie. Człowiek egzystuje, kiedy wychodzi poza siebie i wznosi się ponad siebie. Egzystujemy, kiedy wychodzimy poza zamknięty cykl zaspokajania swoich potrzeb, które nas „uziemiają".

Jeżeli robię coś tylko dla siebie, tylko ze względu na psychiczną równowagę, jeżeli robię to tylko, by osiągnąć homeostazę, jeżeli robię coś tylko po to, by przeżyć przyjemność seksualną czy oszołomienie władzą i tak dalej, to czym jestem? Właściwie nie jestem człowiekiem, ponieważ w tym momencie i w tej mierze nie transcenduję siebie ${ }^{16}$.

Frankl postrzega logoterapię w tradycji filozoficznej, która dokonuje przełamania postawy transcendentalnej, zamieniając zdystansowane do świata i wyłączone ze świata Ja transcendentalne na bycie-w-świecie. „Być człowiekiem znaczy, mówiąc z Martinem Heideggerem, 'być-w-świecie'; to jest w sensie Maxa Schelera 'otwarcie-na-świat"' ${ }^{\prime 7}$. Freud zdetronizował ludzkie Ego, nazywając swoje odkrycie drugim zwrotem kopernikańskim. Pokazał, że wspaniała ludzka świadomość napędzana jest przez, jak je nazwał, bezosobowe siły (es-Kräfte), których istota i pochodzenie są nieznane. Heidegger

\footnotetext{
${ }^{13}$ V. E. Frankl, Die Sinnfrage in der Psychotherapie, s. 170.

${ }_{14}$ Tamże.

${ }^{15}$ V. E. Frankl, Logotherapie und Existenzanalyse, s. 73.

${ }^{16}$ V. E. Frankl, P. Lapide, Gottsuche und Sinnfrage, Gütersloher Verlagshaus, München 2016, s. 118.

${ }^{17}$ V. E. Frankl, Die Sinnfrage in der Psychotherapie, s. 171.
} 
rozpoznał ponadto, że z ludzkim subiektem jako miarą i punktem wyjścia dla wszystkich rzeczy nie jest inaczej. Postawił człowieka w świecie wraz z innymi ludzkimi bytami, wyróżniając go możliwością otwarcia na świat i rozumienia swojego bycia w świecie w prześwicie (Lichtung) bycia samego. Wychodzenie ludzkiej egzystencji poza siebie w stronę świata pozwala się, według Frankla, dobrze wyjaśnić na przykładzie oka. Zdolność oka do spostrzegania świata uzależniona jest paradoksalnie od jego niezdolności do spostrzegania samego siebie. Oko musi siebie przeoczyć, aby widzieć świat.

Dokładnie tak dzieje się także z człowiekiem. Im bardziej człowiek przeoczy siebie, im bardziej zapomni o sobie, w poświęceniu się zadaniu lub poświęceniu na rzecz innych, tym bardziej jest zgodny ze swoim własnym byciem ludzkim ${ }^{18}$.

Humanizm logoterapii i analizy egzystencji Frankla polega na tym, że człowiek staje się człowiekiem za pośrednictwem drugiego lub czegoś innego. Człowiek odkrywa świat w jego sensowności przez kogoś innego lub coś innego. Samotranscendowanie jest drogą do swego rodzaju dialogiczności, w której zarówno inni, jak i rzeczy zyskują dialogiczną wartość. W logoterapeutycznej dialogice człowiek wchodzi w dialog ze względu na sens. To, co człowiek „wkłada”, powierzając się innym lub rzeczom, to powraca do niego $\mathrm{w}$ postaci sensu. W filozofii dialogu istotne jest to, co rodzi się między (zwischen, inter) uczestnikami dialogu. Na przykład rozmowa. W logoterapeutycznej dialogice między biorącymi udział w dialogu, istotny jest sens, który można pozyskać przez doświadczenie drugiego jako kogoś wartościowego lub doświadczenie czegoś jako wartościowego.

Nie wynika to z klasycznych teorii motywacji, że człowiek jest otwarty na świat, że transcenduje siebie samego ku światu, że jest on w poszukiwaniu sensu, który mógłby wypełnić na zewnątrz, w świecie ${ }^{19}$.

Psychologiczne teorie motywacji opierają się na woli działania i wyborze celów działania dla indywidualnego rozwoju. W logoterapii „wola sensu jako pierwotna motywacja" ${ }^{20}$ pobudza do szukania sensu dla urzeczywistnienia egzystencji. Logoterapia pokazuje, że człowiek „zasadniczo ożywiony jest

\footnotetext{
18 Tamże, s. 170.

19 Tamże, s. 171.

${ }^{20}$ V. E. Frankl, Die Sinnfrage in der Psychotherapie, s. 41.
} 
wolą sensu"21, która stoi ponad popędami lub wolą władzy. Wola sensu wyprzedza wszystkie inne pragnienia i dążenia człowieka. Wola sensu oznacza, że człowiek przede wszystkim chce sensu dla dobra swojej egzystencji.

Aby rozjaśnić relację człowieka do świata, Frankl przywołuje słowa Fritza Perlsa, dawnego freudysty, założyciela psychoterapii postaci: „Wydaje ci się, że stoisz przy oknie i patrzysz na świat, ale w rzeczywistości stoisz przed lustrem"22. To znaczy: nie ma zewnętrznego świata, tylko przeglądam się we własnym odbiciu, we własnym świecie. Świat jest niczym innym, jak wyrazem mnie samego, absolutną subiektywnością. Solipsystyczne pojmowanie relacji człowieka do świata obce jest logoterapeutycznemu myśleniu i logoterapeutycznej praxis, dla których otwarta relacja do świata jest podstawą utrzymania zdrowia psychicznego i warunkiem terapii nerwic, objawiających się w zaburzeniach sensownej relacji do świata. Warunkiem sensu jest ludzka zdolność do patrzenia poza własną subiektywną perspektywę, aby za nią spostrzec obiektywną rzeczywistość. W ten sposób mogę się sensownie samourzeczywistnić.

Samourzeczywistnienie jest możliwe dopiero w tej mierze, w jakiej zatracę siebie, zapomnę o sobie, przeoczę siebie. Ponieważ muszę mieć powód, aby siebie urzeczywistnić. Powód polega na tym, że oddam się rzeczy albo osobie ${ }^{23}$.

Samourzeczywistnienie oznacza w codziennym języku realizację własnych celów, pragnień i życzeń, w celu optymalnego rozwinięcia swojej istoty, przez wyczerpujące wykorzystanie swoich umiejętności i talentów. Samourzeczywistnienie, pojęcie filozoficznie i psychologicznie nieokreślone, wyraża indywidualny rozwój, w którym drugi traktowany jest raczej drugorzędnie ${ }^{24}$. Logoterapia wiąże samourzeczywistnienie z kimś lub czymś poza sobą. Droga do samourzeczywistnienia nie prowadzi przez oddanie lub wydanie siebie w akcie autonegacji. Drogą do sensownego samourzeczywistnienia jest logoterapeutyczna redukcja siebie, która otwiera dostęp do świata rzeczy i ludzi. Biorę siebie w nawias, aby spełnić się w powierzaniu się komuś innemu lub czemuś innemu. Powstrzymuję siebie, aby otworzyć sobie możliwość doświadczenia sensu poprzez innych lub coś innego. Samourzeczywistnienie

\footnotetext{
${ }^{21}$ Tamże, s. 171.

22 V. E. Frankl, P. Lapide, Gottsuche und Sinnfrage, s. 53.

${ }^{23}$ Tamże, s. 63.

${ }^{24}$ Niektórzy upatrują kryzys dzisiejszego społeczeństwa w nadmiernym akcentowaniu samourzeczywistnienia jako indywidualnego rozwoju.
} 
jest sensocentryczne. Oznacza urzeczywistnienie możliwości wypełnienia sensu.

Kto traktuje samourzeczywistnienie jako właściwy cel, ten nie dostrzega, że człowiek ostatecznie urzeczywistnia siebie właśnie w tej mierze, w jakiej - na zewnątrz, w świecie - wypełnia jakiś sens. Innymi słowy, samourzeczywistnienie wymyka się wyznaczaniu celów i jest, tak jak szczęście, skutkiem ubocznym wypełniania sensu. Tak więc nie chodzi o urzeczywistnienie samo w sobie i dla siebie, lecz o samostawanie się na drodze okrężnej, poprzez świat i przez rzeczy, przez ludzi, którzy są w świecie i o których musi mi chodzić2 25 .

Sens nie jest tym samym, co cel. Pytaniem logoterpii nie jest Po co, lecz Jak? Logoterapia pyta: jak sensownie wypełnić życie. Człowiek w samostawaniu, orientuje się na drodze możliwości wypełniania sensu, którego skutkiem ubocznym może być osiąganie celów i szczęście. Reinhold Messner, alpinista i himalaista, powiada: „Ani szczyt, ani droga nie są celem - tylko droga okrężna jest celem"26. Na początku w zdobywaniu wielkich szczytów liczył się tylko cel. Potem, gdy szczyty zostały zdobyte, nowa droga na szczyt stała się celem. W końcu celem stała się droga okrężna, to znaczy, najtrudniejsze trasy, pokonywane bez maski tlenowej, w czasie monsunu lub zimą. Sensem logoterapii nie jest prosta droga do celu czy też droga, która jest celem samym w sobie, lecz droga okólna przez świat osób i rzeczy. Droga do sensu jest drogą okrężną. Samarytanin zboczył z drogi do Jerycha, aby wypełnić się sensem. Człowiek, wracając do siebie z drogi okrężnej, jest odmieniony przez sens, którego doświadczył.

Człowiek jest o tyle duchowy, o ile nie przegląda się sam w zwierciadle, nie jest nakierowany na siebie samego, lecz na kogoś lub coś w świecie, przekraczając siebie samego w kierunku Ty. Być człowiekiem znaczy: być intencjonalnie skierowanym na inne bycie i na współczłowiecze bytowanie ${ }^{27}$.

W filozofii transcendentalnej Husserla człowiek kieruje intencjonalną świadomość na świat. Każda świadomość jest świadomością czegoś. Jeżeli przeżywam miłość, to musi być przedmiot miłości. Frankla intencjonalne

\footnotetext{
${ }^{25}$ V. E. Frankl, P. Lapide, Gottsuche und Sinnfrage, s. 64.

${ }^{26}$ R. Messner, Bis ans Ende der Welt. Alpine Herausforderungen im Himalaya und Karakorum, BLV Verlagsgesellschaft, München 1994, s. 7.

${ }^{27}$ V. E. Frankl, P. Lapide, Gottsuche und Sinnfrage, s. 113.
} 
skierowanie na świat jest zamiarem wypełnienia się sensem. Jeżeli powie się komuś, aby się uśmiechnął, to wywoła się na jego twarzy wymuszony grymas. Ale jeżeli opowie mu się dowcip, to ma powód do śmiechu. Jeżeli podziwiam, to znaczy, że jest ktoś godny podziwu. Aby uwierzyć, musi być osoba wiarygodna. Pokładam nadzieję, kiedy jest ku temu podstawa. Aby być kochanym, musi być ktoś godny miłości.

\section{Znaczenia sensu}

Samorozumienie mówi nam: istnieje sens. Rozumiemy bez pomocy teoretycznej wiedzy, że jest coś takiego jak sens. Nie wiemy, czym jest sens, ale z logoterapeutycznego punktu widzenia możemy powiedzieć, że życie ma sens. Sensem życia jest życie sensem. Frankl rozróżnia trzy znaczenia sensu:

1. Sens w życiu (sens sytuacji).

2. Sens (u kresu) życia.

3. Sens (nad-sens) całości.

Ad 1. Sens i życie w analizie egzystencji nie są pojęciami ogólnymi, lecz odnoszą się każdorazowo do naszego życia. Kiedy mówimy o sensie życia, to myślimy o sensie naszego życia. Poszukujemy sensu własnego życia. O sens mogę pytać tylko od siebie i dla siebie. W sensie ścisłym, sens jest określonym sensem określonego miejsca i czasu. „Sens istnieje wszędzie i zawsze. Jednakże tylko w sensie partykularnego sensu. ${ }^{28}$ Sens jest do znalezienia jedynie w aktualnym, faktycznym życiu, w bieżącej, faktycznej sytuacji życiowej.

Pod pojęciem sensu logoterapia rozumie konkretny sens konkretnej osoby, która znajduje się w konkretnej sytuacji i z nią jest konfrontowana. I ten sens jest zawsze czymś jednorazowym i jedynym w swoim rodzaju: jednorazowy o tyle, że może być on tylko teraz urzeczywistniony, ponieważ sytuacja zmienia się nieustannie, a życie jest łańcuchem szybko przemijających sytuacji, a tym samym możliwości sensu. Możliwości sensu są przejściowe, sytuacje są przejściowe. Stąd sens, konkretna możliwość sensu, jest czymś jednorazowym ${ }^{29}$.

${ }^{28}$ V. E. Frankl, Sinnfrage in der Psychotherapie, s. 71.

${ }^{29}$ V. E. Frankl, P. Lapide, Gottsuche und Sinnfrage, s. 117. 
Frankl, stosując grę słów, definiuje sens w jednym z wykładów na Harvardzie: "meaning is what is meant" 30 . Angielską definicję sensu trudno jest oddać w innym języku. Najbliżej daje się ona przełożyć w stylu Heideggera ${ }^{31}$ : sensem jest to, co „sensowi." Sens kryje się w tym, co każdorazowa sytuacja wyraża, co intryguje i zajmuje, co przemawia i absorbuje. Sens w sytuacji wymaga i żąda. „Każda sytuacja stawia przed nami wymaganie, kieruje do nas pytanie - pytanie, na które dajemy odpowiedź, kiedy coś przedsiębierzemy, tak czy tak, jednym słowem, kiedy przyjmujemy ją jako wy-zwanie." 32 Na wymaganiowy charakter sytuacji wskazywał już Max Wertheimer, jeden z głównych założycieli psychologii postaci ${ }^{33}$. Wertheimer w swojej teorii postaci, analizując doświadczenie słuchowe i wzrokowe, odkrył, że rzeczy nie jawią nam się jako pojedyncze części, lecz w całości, figurze, postaci ${ }^{34}$. Całość jest czymś więcej niż sumą jej części. Spostrzeżenie sytuacji nie jest percepcją przypadkowych, bezładnych, oddzielnych części, lecz uchwyceniem sytuacji w jej znaczeniowej całości. Od właściwego uchwycenia sytuacji zależy dokonywanie wyboru i podejmowanie decyzji. W praktyce życiowej niezwykle przydatna umiejętność. Ludzie o ograniczonej zdolności spostrzegania postaci (Gestaltwahrnehmung) sytuacji mają trudności z właściwą na nią reakcją. Doświadczenie postaci sytuacji można rozumieć szerzej niż zmysłowe jej ujęcie. Może ono obejmować całą ludzką egzystencję. W logoterapii spostrzeżenie postaci sytuacji występuje w powiązaniu ze spotrzeżeniem sensu sytuacji.

\footnotetext{
${ }^{30}$ J. B. Fabry, Das Ringen um Sinn, Paracelsus Verlag, Stuttgart 1973, s. 62.

${ }^{31}$ Na przykład, Heidegger mówi: „czas czasowi” (Zeit zeitigt). To znaczy: sens czasu wywodzi się z samego czasu. Czas przynosi. Czas pokaże. Czas leczy. Czas nadchodzi. Czas dzieli i łączy. 32 V. E. Frankl, Logotherapie und Existenzanalyse, s. 269.

${ }^{33}$ Werheimer mówi o „wewnętrznym wymaganiu” (innere Gefordertheit) sytuacji. M. Wertheimer, Untersuchungen zur Lehre von der Gestalt, Gestalt Theory, Band 39, Heft 1, De Gruyter Verlag, Berlin-New York 2017, s. 88.

${ }^{34}$ „To, co istnieje, jest samo w sobie w różny sposób ukształtowane (gestaltet): dane są mniej lub bardziej ustrukturyzowane, mniej lub bardziej określone całości i procesy całościowe, z często bardzo konkretnymi właściwościami całości, z wewnętrznymi prawidłami, charakterystycznymi tendencjami całościowymi z uwarunkowaniem całości dla swych części. 'Kawałki' są zazwyczaj spostrzegane w konkretny sposób 'jako części' w całościowycvh procesach.” M. Wertheimer, Untersuchungen zur Lehre von der Gestalt, s. 84.
} 
W przebiegu spostrzeżenia sensu, jeżeli wolno mi tak powiedzieć, rozbłyska na tle rzeczywistości możliwość, by nie powiedzieć skacze nam do oczu możliwość, aby daną sytuację tak lub inaczej ukszałtować (gestalten) ${ }^{35}$.

Warunkiem doświadczenia sensu jest bycie w sytuacji. Człowiek nie znajduje się w sytuacji, lecz napotyka sytuację, w której pojawia się możliwość sensu. Ani sytuacja, ani możliwość sensu już się nie powtórzą. Przemijają bezpowrotnie. Sens zmienia się od sytuacji do sytuacji, od człowieka do człowieka. Człowiekowi jest dana do urzeczywistnienia taka, a nie inna, jedyna możliwość sensu, w takiej, a nie innej, jedynej sytuacji. Sens sytuacji jest tylko i wyłącznie dla mnie samego. Każdy ma swój własny sens do znalezienia, który jest jedynie jemu przeznaczony. Każdy widzi inną możliwość urzeczywistnienia sensu. Można by „wczuć się" w sytuację drugiego, przez co jego sytuacja mogłaby stać się porównywalnie bliższa mojej, ale nie oznacza to jeszcze, że sens tej sytuacji będzie dla mnie zrozumiały. Nie istnieje wspólne doświadczenie jednego sensu. Nawet jeżeli w sytuację uwikłani są też inni, to każdy z nich widzi daną sytuację z własnej perpektywy. Każdy rozumie tę sytuację po swojemu, ponieważ w niej ukryta jest dla niego jednorazowa i jedyna możliwość urzeczywistnienia sensu. Poszukiwanie sensu jest dla człowieka najwyższym osobistym zadaniem, którego nikt inny z nim nie dzieli.

Jednorazowa sytuacja i jednorazowa możliwość sensu oczekują od jedynego w swoim rodzaju człowieka aktualnej decyzji urzeczywistnienia sensu. "Jeżeli ja tego nie zrobię, to kto to zrobi? I jeżeli tego nie zrobię teraz, to kiedy mam to zrobić?" (Talmud). Nie istnieją tak zwane sytuacje neutralne. W każdej sytuacji człowiek stoi wobec możliwości wyboru sensu lub bezsensu. Życie może być wykorzystywaniem szans w urzeczywistnianiu sytuacyjnego sensu albo też ich zaprzepaszczaniem. Człowiek może rozminąć się z sensem sytuacji lub go przegapić. Na przykład: Matka okazywała czułość synowi, który ją odrzucał. Po jej śmierci brakowało mu tej czułości. Albo: Mądry człowiek nie upublicznił swoich myśli, bo wydawało mu się, że są oczywiste i znane. I tak przepadły. Albo: Ktoś nie miał czasu na rozmowę z człowiekiem zdesperowanym, który potem popełnił samobójstwo. W logoterapeutycznej praxis chodzi o poszczególny sens sytuacji, który może być przedmiotem logoterapeutycznej rozmowy. Przez całe życie stajemy wobec możliwości znalezienia sensu w sytuacji. Nawet w ostatnich chwilach życia człowiek może zachować się sensownie lub bezsensownie.

${ }^{35}$ V. E. Frankl, Logotherapie und Existenzanalyse, s. 269. 
Ad 2. Drugie znaczenie sensu, sens życia, nie odnosi się do poszczególnych sytuacji w życiu, lecz do całości przeżytych sytuacji. Poszukiwanie sensu $\mathrm{w}$ sytuacjach pozostaje $\mathrm{w}$ ścisłym związku $\mathrm{z}$ sensem życia w całości. Życiowe sytuacje składają się na sytuację życia. Kiedy urzeczywistniamy poszczególny sens sytuacji, to wypełniamy się sensem. Przez urzeczywistnianie sensu dojrzewamy i wzrastamy egzystencjalnie. Odczuwamy swoje życie jako bardziej sensowne. Dopóki człowiek żyje, sensowność jego życia pozostaje otwarta. Przychodzi czas, kiedy człowiek znajdzie się u kresu urzeczywistniania możliwości wypełniania sensu i może wstecz spojrzeć na swoje życie. Życie rozpościera się przed nim w przeżytych sytuacjach, jak klatki filmu.

Film ma swój sens jako całość, ale objawia nam się on dopiero wtedy, gdy widzimy te obrazy w kontekście całości. Sens życia objawia nam się dopiero, kiedy leżymy na łożu śmierci. W najlepszym wypadku ${ }^{36}$.

Film składa się z wielu scen, a każda poszczególna scena przybliża widzowi sens całości. Sens całego filmu odsłania nam się dopiero pod koniec seansu, zakładając, że przedtem uchwyciliśmy sens każdej poszczególnej sceny. W naszym życiu dzieje się podobnie:

Czy sens naszego życia nie odsłania nam się, o ile w ogóle, dopiero na końcu? Czy ten końcowy-sens naszego życia nie zależy też od tego, czy kiedyś najpierw nie wypełnialiśmy sensu każdej poszczególnej sytuacjii ${ }^{37}$

Życie jest sensowne, o ile jego sens został zbudowany w konkretnych i poszczególnych sytuacjach życiowych. Sens życia nie zależy od jego długości i nie leży też $\mathrm{w}$ jego przedłużaniu. Dłuższe życie nie jest sensowniejsze niż krótsze. Sens życia jest w istocie sensem przeżytych sytuacji. Sens, który człowiek budował w ciągu swojego życia, nie zapadł się w bezpowrotną przeszłość i nie zniknął. Wypełniony sens należy już na zawsze do naszego życia.

Wszystko, co robimy, przeżywamy, a nawet to, co wycierpimy jest wstąpieniem w przeszłość, gdzie nic i nikt już nie może tego zrabować. To, co raz zrobimy, kiedy podejmujemy i ujmujemy jedyną $\mathrm{w}$ swoim rodzaju okazję do wypełnienia sensu, to zrobiliśmy raz na zawsze, uwieczniliśmy to, dokonaliśmy tego dla

\footnotetext{
${ }^{36}$ Tamże, s. 118.

${ }^{37}$ V. E. Frankl, Der unbewußte Gott. Psychotherapie und Religion, Kösel Verlag, München 2017, s. 88.
} 
wieczności, gdzie jest to zabezpieczone, zachowane, w sensie bycia przechowanym $^{38}$.

Do przeszłości należy wszystko, co przeżyliśmy, ale pozostaje tylko to, co miało sens. „Ty zapisałeś moje życie tułacze; Ty przechowałeś łzy moje w bukłaku: czyż nie są one zapisane w Twej księdze." (Psalm 56). Trwałe jest tylko to, co było sensowne. Nawet to, co bolesne, sensownie przeżyte, zachowane jest w sposób nienaruszony w przeszłości. To, co miało sens powraca z przeszłości i towarzyszy ludzkiej egzystencji aż do końca. W obliczu śmierci pojawiają się pytania i wątpliwości, czy życie było ostatecznie sensowne? Czy na podstawie tego, co się zrobiło, zwłaszcza jeżeli ma się wrażenie, że nie było to nic specjalnego, można uznać życie za sensowne? Gdzie można wypatrzeć jeszcze sens, kiedy życie obfitowało w mało sensowne pociągnięcia? Aby odpowiedzieć na te pytania, rozwiać wątpliwości i upewnić się co do sensu całości życia, potrzeba często logoterapeutycznej pomocy.

Ad 3. Jeżeli sens w życiu i sens życia występują w granicach możliwości rozumienia człowieka, to trzecia kategoria sensu, sens całości, leży poza ludzkim rozumieniem i poznaniem. Sens całości jest sensem metafizycznym. „Sens świata, universum jest nad-sensem." ${ }^{39}$ Sens całości świata kryje się za wszystkimi poszczególnymi możliwościami sensu i za możliwością rozumienia ostatecznego sensu ludzkiego życia. Sensu całości nie potrafimy poznawczo uchwycić. O nim nie istnieje żadna wiedza. „Całość nie ma sensu - ona ma nadsens. [...] Niemożliwe jest pomyśleć nadsens; tak więc jest konieczne w niego wierzyć." ${ }^{40}$ Chodzi o wiarę, która bliska jest wierze religijnej, ale która jest bardziej intensywna niż wiara religijna. Wiara $\mathrm{w}$ sens pozostaje, gdy znikną rzeczy, które dodatkowo nadawały sens życiu. Na wierze w sens można budować, kiedy opuszczą nas inne sensy. Wiara w sens nie mówi nic innego, jak to, że sens jest możliwy do odnalezienia w świecie. W sytuacji życiowej człowiek stoi nieustannie wobec wyboru możliwości sensu. Jedyna możliwość, przed jaką człowiek stoi w odniesieniu do ostatecznego pytania o sens, leży w wyborze wiary albo niewiary w sens. W sens całości człowiek może wierzyć lub nie wierzyć. Sens całości może być w wierze przyjęty, bądź w niewierze odrzucony. Jeżeli człowiek przyjmie, że świat jako całość jest sensowny, to ma szansę znaleźć sens w sytuacjach życiowych. Wiara w sens daje

\footnotetext{
${ }^{38}$ Tamże, s. 125.

39 Tamże, s. 118.

${ }^{40}$ V. E. Frankl, Der leidende Mensch. Anthropologische Grundlagen der Psychotherapie, Huber Verlag, Bern 1984, s. 201.
} 
człowiekowi głębokie i ostateczne metafizyczne zakorzenienie. Wiara w sens jest darem, którym nie wszyscy tak samo zostali obdarowani. Ktoś dzięki wierze $\mathrm{w}$ sens, może przenosić góry. Ktoś inny, mimo wiary w sens, potrafi zaledwie sensownie przeżyć codzienność.

Nie pozostaje nam nic innego, jak przyjąć, że 'natura' miała tu na pewno coś na myśli, jeżeli daje nam możliwość znajdowania sensu, jednym słowem, on sama, ze swojej strony musi podążać za sensem, nawet jeżeli nie zastanawiamy się nad nim. Jeżeli natura stworzyła sens, to musi sama i ze swojej strony mieć także sens $^{41}$.

„Czy ten, co stworzył oko - miałby nie widzieć? Czy ten, co stworzył ucho - miałby nie słyszeć" (Psalm 94). Jako istoty skończone mamy ograniczoną zdolność widzenia i rozumienia sensu, jaki kryje się w sytuacjach życiowych. Jako istoty podlegające rozpadowi nie potrafimy bez wątpienia wierzyć w sens świata jako całości. Sens całości świata jest ukryty dla naszego postrzegania i rozumienia i wymyka się naszej chwiejnej wierze. Poznanie świata nie potrafi jednoznacznie pokazać, czy świat jako całość jest sensowny, czy bezsensowny. Mysz jest szara, aby mogła ukryć się w polu, a orzeł ma bystre oczy, aby ją tam wypatrzeć. Czy w ogóle jest sens szukać odpowiedzi na pytanie o sens świata? Czy musimy w ogóle pytać Po co w odniesieniu do świata?

Dzisiaj stoją naprzeciw siebie dwa różne, wrogo do siebie nastawione obozy duchowe: „fundacjonaliści” (Fundationalisten), dla których odpowiedzialne myślenie szuka ugruntowania i ,antyfundacjonaliści” (Antifundationalisten), którzy nie widzą konieczności ugruntowania myślenia ${ }^{42}$. Jeżeli zawiesza się konieczność ufundowania i uzasadniania myślenia, a tym samym, konieczność stawiania pytania Dlaczego, to można też zawiesić konieczność szukania odpowiedzi na pytanie Po co świata. „Po co 'po co"' ${ }^{33}$ pyta, wcale nie retorycznie, Frankl.

Żadna nauka nie jest w stanie znaleźć i określić pełnego, wszystko ogarniającego sensu świata. „Im bardziej sens jest wyczerpujący, tym mniej daje się

\footnotetext{
${ }^{41}$ Tamże, s. 72.

${ }^{42}$ J. Greisch, „Warum denn das Warum”. Heidegger und Meister Eckhart: von der Phänomenologie zum Ereignisdenken, [w:] N. Fischer, Fr. W. von Herrmann (hrsg.), Heidegger und die christliche Tradition, Felix Meiner Verlag, Hamburg 2007, s. 132.

${ }^{43}$ V. E. Frankl, Die Sinnfrage in der Psychotherapie, s. 72.
} 
ująć ${ }^{44}$. Ostateczny sens całkowicie wymyka się racjonalnemu dostępowi. To, czego nie można wiedzieć, nie musi być jednak niewiarygodne.

W obliczu pytania, czy wszystko ma sens, choćby zakryty, czy świat jest jednym wielkim bezsensem, nauka musi ustąpić pola - to jest wiara, która wzywa tutaj do podjęcia decyzji. Tam, gdzie argumenty, które opowiadają się za lub przeciw ostatecznemu sensowi, utrzymują wzajemnie wagę, wierzący-w-sens człowiek rzuca na szalę cały ciężar swojego bycia - człowiekiem, swojej egzystencji ${ }^{45}$.

Poszukiwanie sensu poprzedza zarówno powiedzenie „tak” życiu, jak i powiedzenie „tak” sensowi. Utrzymywanie, że świat jest bezsensowny, jest wyrazem niewiary w sens świata i niewiary w możliwość urzeczywistnienia sensu. Jeżeli człowiek nie wierzy w sens, to trudno mu zrozumieć, że życie może być sensowne. Nie można szukać sensu w świecie, który jest bezsensowny. Deklaracja Sartrea „Bezsensowne jest to, że się urodziliśny i bezsensowne jest, że umieramy" nie jest właściwie wyborem niewiary w sens. Pozostawia bowiem możliwość sensownego życia, mimo niezrozumiałego sensu pojawienia się w świecie i „bezsensu” opuszczenia świata. Zatrzymaliśmy się i przebywamy w świecie. Nawet jeżeli człowiek nie rozumie sensu swojego pochodzenia i „sensu” przeznaczenia, to pozostaje mu życie, które choćby dla dobrego samopoczucia, warto sensownie ukształtować.

\section{Sens sytuacji}

Sytuacja jest na ogół rozumiana jako kontekst, otoczenie, okoliczność, ramy przestrzenne, wewnętrzna „pozycja” myślenia i przeżywania. Sytuacja jest zasadniczo określona przez miejsce i to, co go otacza. Frankla pojęcie sytuacji może być zrozumiałe na podłożu Heideggera analiz bycia ludzkiego i sytuacji.

Dla Heideggera sytuacja jest sytuacją ugruntowaną w „byciu-w-świecie” (In-der-Welt-sein). Bycie w świecie stanowi podstawową sytuację bycia ludzkiego. Heidegger rozumie sytuację jako „bycie w położeniu” (in der Lage

\footnotetext{
${ }^{44}$ Tamże, s. 73.

${ }^{45}$ V. E. Frankl, Der unbewußte Gott, s. 99.
} 
sein $)^{46}$. Egzystencja egzystuje w określonym położeniu przestrzennym. Położenie w przestrzeni fizykalnej różni się od położenia w przestrzeni egzystencjalnej, określonej przez kategorie, „oddalenia” (Entfernung) i „nakierowania" (Ausrichtung). Położenie nie jest przypadkowe, lecz jest położeniem względem czegoś i zorientowanym na coś. Ludzkie bycie wchodzi w sytuację przez „otwarcie” (Erschlossenheit). Sytuacja staje się dostępna dzięki otwarciu. Sytuacja nie jest gotową ramą, w której pojawia się bycie ludzkie lub sytuacją, w którą ono się wpędziło. Sytuacja znajduje swoje ugruntowanie w „zdecydowaniu" (Entschlossenheit). To znaczy: egzystencja rozstrzyga o możliwości bycia lub nie bycia w sytuacji. W otwartą sytuację wchodzę zdecydowanie. Mogę być obojętnym na sytuację, ale wtedy jestem narażony na uwikłanie się w przypadkowe okoliczności. Dla „bycia niesobowego” (das Man), wyrażającego degradację bycia ludzkiego i pozbawionego możliwości otwarcia, sytuacja jest zamknięta. Niesobowe bycie zna tylko „ogólne sytuacje”, zatraca się w przypadkowych okazjach i bytuje od przypadku do przypadku.

Później Heidegger będzie wiązał sytuację z dziejami. Mówi się o sytuacji historycznej, to znaczy, sytuacji doniosłej, mającej utrwalić się w pamięci historycznej. Historyczna sytuacja jest „ogólną sytuacjąa i niewiele ma wspólnego z sytuacją egzystencji. Ktoś, kto stoi w tłumie na wiecu lub demonstracji, uczestniczy w sytuacji historycznej. W przeciwieństwie do sytuacji historycznej Heidegger wprowadza określenie „dziejowej konstelacji” (geschichtliche Konstellation $)^{47}$. Dzieje egzystencji tworzą całość sytuacyjną, powstałą z wzajemnego spotkania się określonych sytuacji.

Heidegger rozumie sytuację jako „sytuację faktyczną" 48 i „sytuację hermeneutyczną" "', w której porusza się życie. Życie może rozumieć siebie i wyjaśnić siebie w sytuacji. W teologii biblijnej utrwaliło się, wprowadzone przez protestanckiego biblistę Hermanna Gunkela, pojęcie „osadzenie w życiu” (Sitz im Leben), odnoszące się do Słowa Bożego, które może być zrozumiałe w kontekście historycznej sytuacji życiowej ${ }^{50}$. Na przykład to, kim rzeczy-

${ }^{46}$ M. Heidegger, Sein und Zeit, Gesamtausgabe, Bd. 2, Unveränderter Text aus dem „Hüttenexemplar", hrsg. von Fr. W. von Herrmann, Vittorio Klostermann, Frankfurt am Main 1977, s. 379.

${ }^{47}$ M. Heidegger, Bremer und Freiburger Vorträge, Gesamtausgabe, Bd. 79, hrsg. von P. Jaeger, Vittorio Klostermann, Frankfurt am Main 2005, s. 99.

${ }^{48}$ Tamże, s. 366.

${ }^{49}$ Tamże, s. 351.

${ }^{50} \mathrm{H}$. Gunkel, Die israelitische Literatur, Verlag Wissenschaftliche Buchgesellschaft, Darmstadt 1963, s. 10. 
wiście byli faryzeusze, możemy wiedzieć poprzez analizę życia społecznego i religijnego w tamtych czasach w Palestynie. Życie utrwalone w słowie lub faktyczne życie może być zrozumiałe i uchwycone w sytuacji i wyjaśnione w kontekście sytuacji.

Heidegger pokazuje doświadczenie sensu w życiowej sytuacji. Nie chodzi o to, aby nadać światu teoretycznie sens, tylko o to, aby „widzieć sens, w którym to, co faktycznie doświadczane ma charakter znaczeniowości" ${ }^{\prime 1}$. Odkrywamy pierwotnie świat $w$ jego znaczeniowości. Nie nadajemy znaczeń, tylko widzimy świat w rozmaitych znaczeniach. To, czego doświadczamy w życiu ma znaczenie, nawet to, co jest najbardziej niepozorne lub bezwartościowe. Doświadczane rzeczy świata nie są jedynie kształtnymi i barwnymi rzeczami, lecz coś dla nas znaczą. Patrzę przed siebie i widzę znaczące rzeczy: stół, okno dachowe, książki, przybory do pisania. Egzystowanie polega na doświadczaniu świata w jego znaczeniowości. „, Sens 'egzystencji' leży w faktycznym życiu, w aktualnie doświadczanych, przypominanych albo oczekiwanych znaczeniowościach" ${ }^{2}$. Świat sam w sobie jest sensowny. Sens świata leży w tym, że coś znaczy. To jest „immanentny sens doświadczanej rzeczywistości świata"53. Znaczeniowść świata umożliwia w ogóle doświadczenie jego znaczenia. Bycie znaczenia poprzedza znaczenie bycia. Rzeczy świata jawią nam się w znaczeniach i kontekstach znaczeniowych.

Tak więc nie jest tak, że faktyczne doświadczenie świata ze względu na sens rzeczywistości [...] mogłoby być scharakteryzowane jako sąd o wartości albo o szczególnym znaczeniu tego, co właśnie jest doświadczane ${ }^{54}$.

Doświadczając sensu (znaczenia) świata, musimy powstrzymać się przed nadawaniem rzeczom świata wyimaginowanej wartości lub dodatkowego znaczenia. Filozofia wzywa nas do doświadczenia sensu (znaczenia) rzeczy takimi, jakimi są. Sens (znaczenie) rzeczy może odsłonić się nam tylko w nieuprzedzonej postawie poznawczej.

\footnotetext{
${ }^{51}$ M. Heidegger, Grundprobleme der Phänomenologie, Bd. 58, s. 110.

${ }^{52}$ Tamże, s. 106

${ }^{53}$ Tamże, s. 108.

${ }^{54}$ Tamże, s. 109.
} 
Odgraniczenie sensu 'znaczeniowości' od 'celowości' w sensie urzeczywistnienia uprzednio pomyślanej albo możliwej do pomyślenia idei. Znaczeniowość jest bogatsza i może być uboższa; nie leży w tej samej sferze sensu ${ }^{55}$.

Heidegger odróżnia znaczenie bycia od sensu bycia. Znaczenie i sens przynależą do odmiennych „sfer sensu" bycia. Widzenie znaczenia dokonuje się w bezpośrednim doświadczeniu świata. Przeżycie sensu egzystencji może dokonać się ze względu na ideę. Jedno doświadczenie nie wyklucza drugiego. Oba przynależą do siebie. Rozpoznanie znaczenia świata rzeczy współstnieje $z$ urzeczywistnieniem sensu przez ideę. Widzenie znaczenia sytuacji życiowej może wpłynąć na nasze przeżycie sensu. Jednakże nawet najlepsze widzenie znaczenia rzeczy w świecie nie może zastąpić urzeczywistnienia sensu przez doświadczenie idei. Widzenie znaczeń świata jest podobne do widzenia znaków drogowych w ruchu ulicznym. Umożliwia ono co prawda orientowanie się i radzenie sobie świecie, ale nie przynosi sensu naszej egzystencji.

\section{Sens sytuacji logoterapeutycznej}

W logoterapii sens jest sensem sytuacji życiowej. Sytuacja życiowa niekoniecznie musi być związana z ludźmi. Sytuacja nie jest tylko sytuacją etyczną, o której sensowności decyduje wybór dobra lub zła. Kiedy spacerujemy w parku, kiedy dotyka nas cierpienie, kiedy stoimy przed zadaniem albo przychodzi nam na myśl jakaś idea - wtedy znajdujemy się w sytuacji. Sens sytuacji nie jest nieokreślonym, wymarzonym, sprojektowanym sensem. „W kontekście logoterapii przez sens nie rozumie się nic abstrakcyjnego, lecz chodzi o konkretny sens konkretnej sytuacji." ${ }^{56}$ Kiedy medytujemy podczas spaceru, to ta medytacja jest konkretnym sensem. Kiedy znosimy spokojnie cierpienie, to ten spokój jest konkretnym sensem. Kiedy architektowi przychodzi na myśl piękny i funkcjonalny dom, to ta idea jest konkretnym sensem. Sensu możemy szukać, począwszy od prostych sytuacji życiowych, poprzez sytuacje, jakie stawia nam wykonywanie zadań, aż po sytuacje, w które zostajemy wpędzeni przez los. „Nie ma sytuacji życiowej, która byłaby rzeczywiście bezsen-

\footnotetext{
55 Tamże.

${ }^{56}$ V. E. Frankl, Logotherapie und Existenzanalyse, s. 268.
} 
sowna." ${ }^{57}$ Każda sytuacja zawiera w sobie potencjalną możliwość znalezienia sensu. Sytuacje będą mogły być sensownie ukształtowane, jeżeli „napotkamy je z właściwą postawą i nastawieniem" ${ }^{38}$. Możliwość znalezienia sensu leży w zajęciu stanowiska wobec sytuacji, jaką człowiek napotkał, niezależnie od tego, czy jest to sytuacja z życia codziennego, czy sytuacja związana z zadaniem, czy sytuacja losowa. To, że stajemy ciągle w sytuacji i mamy zająć wobec niej jaką́s postawę, jest samo przez się zrozumiałe. „O tym wie człowiek z ulicy." ${ }^{59}$ Nie każdy potrafi wyrazić słowami, że musi stawić czoła sytuacjom życiowym. Zadaniem logoterapii jest pokazanie możliwości sensownego wypełnienia życia. Dla „człowieka z ulicy” życie nie jest placem ścierania się sił popędowych (Freud) i pędu do władzy (Adler) z osobowym Ja.

Lecz życie jest dla niego łańcuchem sytuacji, w które jest postawiony, z którymi ma się uporać, które każdorazowo mają określony sens, który jego samego obchodzi i absorbuje. I najbardziej źródłowa samozrozumiałość mówi mu, że wszystko musi postawić na to, aby ten sens odnaleźć i wytropićc ${ }^{60}$.

Logoterapia nie wydaje orzeczeń o wartości życia, lecz wskazuje na samozrozumiałość poszukiwania sensu w sytuacji. Człowiek rozumie sam z siebie, zanim powie mu o tym tradycja, teoria lub religia, że ma najpierw i przede wszystkim szukać sensu.

Sens ludzkiego życia nigdy nie może być dany ogólnie, nigdy nie można na pytanie o sens życia odpowiedzieć ogólnie - życie, tak jak jest ono tutaj rozumiane, nie jest czymś mglistym, lecz każdorazowo czymś konkretnym, i w ten sposób także wymagania życia są wobec nas każdorazowo całkowicie konkretne. Ta konkretność przynosi ze sobą przeznaczenie człowieka, które jest dla każdego jednorazowe i jedyne w swoim rodzaju. I w każdej sytuacji człowiek jest wezwany do sensownego zachowania. Raz konkretna sytuacja żąda od niego, że podejmnie działanie, że będzie usiłował swoje przeznaczenie ukształtować w działaniu, innym razem, że skorzysta z okazji, aby w przeżywaniu urzeczywistnić możliwości wartości, jeszcze innym razem, że pokornie weźmie na siebie los. Ale zawsze każda sytuacja wyróżnia się przez ową jednorazowość

\footnotetext{
${ }^{57}$ V. E. Frankl, Der unbewußte Gott, s. 76.

${ }^{58}$ Tamże.

59 Tamże.

${ }^{60}$ Tamże, s. 77.
} 
i jedyność, która dopuszcza każdorazowo tylko jedną i jedyną, właściwą odpowiedź, która zawarta jest w konkretnej sytuacji ${ }^{61}$.

Nieuniknioność przeznaczenia, które domaga się przyjęcia sensownej postawy wobec sytuacji nie jest przytłaczająca, lecz wyzwalająca. Przyjęcie sensownej postawy w sytuacji wznosi się ponad panowanie popędów, wolę władzy lub stany neurotyczne. Gdzie nie może przebić się logika sensu, tam dochodzi do głosu, sterowana popędami, wolą władzy lub nerwicami, retoryka panowania nad sytuacją, kontrolowania sytuacji, unikania sytuacji, ignorowania sytuacji, niewidzenia wyjścia z sytuacji beznadziejnej. Gdzie człowiek przyjmuje sensowną postawę wobec sytuacji, tam potwierdza to, co jest w nim najbardziej ludzkie: wolność wyboru i decyzji.

Obiektywność czegoś takiego jak sens nie wyklucza jego subiektywności. Sens jest subiektywny w tym sensie, że nie istnieje jeden sens dla wszystkich, lecz dla każdego inny sens; sens, o który każdorazowo chodzi, nie może być czysto subiektywnym sensem; nie może być czystym wyrazem i odbiciem lustrzanym mojego bycia ${ }^{62}$.

Subiektywność i relatywność sensu oznaczają, że występuje on w relacji do człowieka i sytuacji, w którą ta osoba jest postawiona i uwikłana. Sens zostaje urzeczywistniony ze względu na poszukującego człowieka i sytuację, w której się znajdzie. W tym sensie sens sytuacji jest rzeczywiście subiektywny i relatywny. Urzeczywistnienie obiektywnego sensu dokonuje się zawsze z perspektywy człowieka i sytuacji w świecie. Urzeczywistnienie sensu jest urzeczywistnieniem możliwości sensu. „Przy spostrzeżeniu sensu chodzi o odkrycie możliwości na tle rzeczywistości. A mianowcie chodzi o możliwość zmiany rzeczywistości." ${ }^{33}$ Człowiek jest istotą w poszukiwaniu sensu, który może być odnaleziony. W przebiegu spostrzeżenia sensu na tle rzeczywistości pojawia się możliwość, aby daną sytuację tak a tak sensownie ukształtować. Raz urzeczywistniona możliwość jest na zawsze urzeczywistniona. Nie ma powtórek możliwości. Istnieją zaprzepaszczone, nieurzeczywistnione możliwości sensu. „Osoba ma ująć i podjąć sens sytuacji, uwierzyć,

${ }^{61}$ V. E. Frankl, ... trotzdem Ja zum Leben sagen. Ein Psychologe erlebt das Konzentrationslager, Kösel Verlag, München 1982, s. 125.

${ }^{62}$ V. E. Frankl, Ärztliche Seelsorge. Grundlagen der Logotherapie und Existenzanalyse. Mit den „Zehn Thesen über die Person“, Deuticke im Paul Zsolnay Verlag, Wien 2015, s. 86.

${ }^{63}$ V. E. Frankl, Die Sinnfrage in der Psychotherapie, s. 59. 
spostrzec i uznać za prawdziwy, mianowicie urzeczywistnić." ${ }^{64}$ Aby urzeczywistnić sens, trzeba najpierw rozpoznać logiczne znaczenie sytuacji, w której wypełni się sens. Bez właściwego rozpoznania i rozeznania sytuacji trudno jest dokonać właściwego wyboru możliwości, w której urzeczywistni się sens. Frankl porównuje zachowanie człowieka w sytuacji, która stawia przed nim możliwość wypełnienia sensu, do szachisty, stojącego przed możliwością dokonania optymalnego posunięcia szachowego.

Jednakże pytanie, czym jest 'ten' sens życia, w swojej naiwności, podobne byłoby do pytania: jakie jest najlepsze posunięcie szachowe na świecie? Takiego posunięcia oczywiście nie może być, ponieważ każde posunięcie szachowe musi się kierować według sytuacji w danej partii szachowej, a także według osoby partnera gry ${ }^{65}$.

Teoretycznie nie jest możliwe ustalenie najlepszego posunięcia. Podobnie człowiek, który uczestniczy w grze życia, aby wykonać sensowny ruch, musi wziąć pod uwagę sytuację i możliwość zachowania współgrającego.

Frankl rozróżnia trzy podstawowe sposoby bycia człowieka w świecie: „przystosowanie”, „kształtowanie” i „wypełnienie” ${ }^{66}$. Celem psychonanalizy Freuda jest, ogólnie rzecz biorąc, wytworzenie kompromisu między roszczeniami tego, co nieświadome z jednej strony i wymaganiami rzeczywistości z drugiej strony, to znaczy przystosowania popędliwości do rzeczywistości. Psychologia indywidualna Adlera, przeciwnie, przekraczając skłonności indywiduum do przystosowania, przyjęła za psychoterapeutyczną dewizę odważne ksztattowanie rzeczywistości ze strony Ja. Oprócz przystosowania i kształtowania występuje w człowieku jeszcze jedno dążenie, przez które człowiek może się w całej pełni urzeczywistnić. Istnieje jeszcze jeden sposób bycia w świecie, który trzeba wziąć pod uwagę, kiedy myślimy o pełnym psychofizyczno-duchowym obrazie człowieka. Ten sposób bycia „może być $w y$ pełnieniem znalezienia sensu" ${ }^{\prime 67}$. Wypełnienie sensem wychodzi o wiele dalej, jakościowo dalej, w rozumieniu dążeń człowieka niż freudowskie przystosowanie do rzeczywistości i adlerowskie kształtowanie rzeczywistości.

\footnotetext{
${ }^{64}$ V. E. Frankl, Ärztliche Seelsorge, s. 86.

${ }^{65}$ V. E. Frankl, Logotherapie und Existenzanalyse, s. 294.

${ }^{66}$ Tamże, s. 17.

${ }^{67}$ Tamże.
} 


\section{Wypełnienie sensu przez urzeczywistnienie wartości}

Poszukiwanie sensu w sytuacji jest nakierowane na wartości. Jeżeli psychoanaliza nastawiona jest na przeszłość i przyczynowość, a psychologia indywidualna na przyszłość i celowość, to psychoterapia w sensie logoterapii nastawiona jest na teraźniejszość (sytuacji) i ponadczasowość (wartości) „na to, co absolutne w sensie obiektywnych wartości”"68. Człowiek nie jest popędzany do przeżycia wartości. Nie musi ich urzeczywistniać. Przeżywanie wartości nie leży też w obszarze samowoli. Człowiek odczuwa w sobie powinność wobec wartości.

Znajdowanie sensu jest ukierunkowane, a mianowicie ukierunkowane na ową możliwość wartości, zastrzeżoną dla każdej pojedynczej ludzkiej osoby, albo lepiej powiedziawszy, jej zadaną, którą trzeba wypełnić; jest nakierowane na te wartości, które każdy pojedynczy człowiek ma do wypełnienia, w jednorazowości swojej egzystencji i jedyności swojej przestrzeni przeznaczenia ${ }^{69}$.

Powinność urzeczywistniania wartości nie jest przymusem i nie kłóci się z wolnością. „Dla analizy egzystencji przed chcę stoi świadome powinienem - dla psychodynamiki za świadomym chcę stoi nieświadome muszę"70. Człowiek odczuwa, że powinien działać według wartości, aby wypełnić swoje przeznaczenie. Czyny dokonane z powinności bywają niezrozumiałe z zewnątrz. Tylko ten, kto zrobił tak, jak trzeba, wie o ich sensie. „Człowiek jest pociągany przez to, co wartościowe" ${ }^{\prime 1}$. Między przyciąganiem wartości i powinnością wobec wartości występuje napięcie, które wyzwala energię do ich urzeczywistnienia, podobnie jak dwie zbliżone do siebie elektrody generujące iskrę. To egzystencjalne napięcie nazywa Frankl „noodynamiką w przeciwieństwie do psychodynamiki”72. Psychodynamika jest afektywno-popędową dynamiką, wypełniającą człowieka życiową energią. Psychodynamika jest podbudową noodynamiki (dynamiki duchowej, nous - duch), która wyzwala energię do duchowego życia. Do urzeczywistniania wartości człowiek nie jest skłaniany, pchany czy popędzany. Nie mogę urzeczywistniać wartości

\footnotetext{
${ }^{68}$ Tamże, s. 18.

${ }^{69}$ Tamże, s. 17.

70 Tamże, s. 105.

${ }^{71}$ Tamże, s. 106.

${ }^{72}$ V. E. Frankl, Ärztliche Seelsorge, s. 108.
} 
wbrew swojej woli. „Na urzeczwistnienie wartości decyduję się w wolności i odpowiedzialności, aby urzeczywistnić wartości otwieram się, otwieram sobie drogę do świata wartości" ${ }^{\prime 3}$. Otwarcie na wartości poprzedzone jest otwarciem na świat, bo tylko w rzeczywistym świecie mogę je urzeczywistnić. Otwarcie się na kosmos wartości potwierdza obecność w człowieku pierwotnego przedrozumienia i pierwotnej wrażliwości na wartości.

Każda sytuacja stawia człowieka wobec możliwości wypełnienia sensu przez przeżycie wartości lub przeżycia bezsensu w odwróceniu się od wartości. „Przypominamy sobie tę definicję Maxa Schelera, według której zdrowie (Heil) człowieka leży w wypełnieniu jego najwyższych możliwych wartości”" Sensowna, zdrowa egzystencja to taka egzystencja, która urzeczywistnia najwyższe możliwości wartości. „J. H. Schultz (twórca treningu autogennego), mówi o 'wyższych egzystencjalnych warstwach wartości' i wyraża się o nich: 'Kto jest w nich zadomowiony, ten może cierpieć, nie stając się chorym, neurotycznie chorym."' 75 Egzystencjalne urzeczywistnianie wartości jest istotne dla zdrowia psychicznego i higieny psychicznej. Kto żyje według wartości i unika konfliktów wartości, chroni się przed nerwicami i zachowuje zdrowie psychiczne.

Uniwersalne, ogólnie obowiązujące wartości nabierają sensu, jeżeli stają się relatywnie wiążące w konkretnej sytuacji życiowej.

Jednak przykazania były zawsze i pozostają nadal ogólnymi przykazaniami, obowiązującymi w całej historii ludzkości i we wszystkich społeczeństwach. Ale w szczegółowych przypadkach właśnie nie. To znaczy: ogólnie nie powinno się kraść, składać fałszywego świadectwa, łamać małżeństwa, ale sens w logoterapii, tak jak ja go rozumiem, w ramach logoterapii, - w konfrontacji z konkretnym, jedynym w swoim rodzaju człowiekiem i jednorazową sytuacją - tu muszę mówić o konkretnym sensie. Wartości, a także przykazania są, innymi słowy, ogólnymi przewodnikami działania. Sens jest czymś konkretnym, ponieważ każda osoba jest jednorazowa i każdorazowa sytuacja jest jedyna i konkretna $^{76}$.

Gdzie chodzi o życie, o ratowanie własnego lub innego życia, tam dozwolone jest przekraczanie przykazań. „Już przed 2000 laty Rabini mówili: Aby

\footnotetext{
${ }^{73}$ W. E. Frankl, Logotherapie und Existenzanalyse, s. 106.

${ }^{74}$ Tamże, s. 18.

75 Tamże.

${ }^{76}$ V. E. Frankl, P. Lapide, Gottessuche und Sinnfrage, s. 60.
} 
ratować życie ludzkie, także swoje, nie tylko wolno ci, lecz powinieneś łamać wszystkie pozostałe przykazania." 77

„Wypełniamy sens bycia ludzkiego - nasze bycie ludzkie wypełniamy sensem - zawsze przez to, że urzeczywistniamy wartości." ${ }^{78} \mathrm{~W}$ każdej sytuacji, w jakiej znajdzie się człowiek jako wolna istota, stoi on przed wyborem wartości, dzięki którym może wypełnić się sensem lub nie. W analizie egzystencji rozumiemy sens ze względu na wartości. Sens nie jest tym samym, co wartości. Podczas gdy sens jest i pozostaje taki sam, wartości są różne i występują $\mathrm{w}$ systemie i hierarchii. Poza tym sens jest partykularnym sensem sytuacji, a wartości są ogólne i uniwersalne. Jeżeli jednak weźmiemy sens i wartości jako określenia stanu rzeczy, to możemy rozumieć je synonimicznie. W pewnym sensie to, co jest wartościowe, jest sensowne. A to, co jest sensowne, jest wartościowe. Problem znalezienia sensu jest problemem przeżycia wartości. Pytanie o sens jest jednocześnie pytaniem o wartości. Czym są wartości? Przez co otrzymują wartości swoją wartość?

Nie ma psychoterapii bez wartości. „Psychoterapia, która uważa się za wolną od wartości, w rzeczywistości jest ślepa na wartości." ${ }^{\text {'9 }}$ Czy to nie narusza statusu bezstronności światopoglądowej psychoterapii, która musi liczyć się z indywidualnym systemem wartości człowieka cierpiącego na nerwicę? Czy i jak jest możliwa psychoterapia wartościująca? Czy psychoterapia może zakładać jakiś porządek wartości? Frankl widzi takie rozwiązanie tego pytania: „Istnieje jedna formalna etyczna wartość, która sama jest warunkiem wszelkiego dalszego wartościowania: odpowiedzialność!"80 Odpowiedzialność jest fundamentalną wartością. Do odpowiedzialności można się odwołać, bez względu na światopogląd, system etyczny, przyjęty porządek wartości. Odpowiedzialność jest wartością globalną ${ }^{81}$. Nawet jeżeli ktoś odrzuca wszelki światopogląd, system etyczny czy porządek wartości, to musi liczyć się z wartością odpowiedzialności. Każdego można rozliczyć z odpowiedzialności i pociągnąć do odpowiedzialności. „Według analizy egzystencji to, za co człowiek jest odpowiedzialny, to jest wypełnienie sensu i urzeczywistnienie

\footnotetext{
77 Tamże, s. 61.

${ }^{78}$ V. E. Frankl, Der leidende Mensch, s. 202.

79 Tamże, s. 60.

80 Tamże, s. 43.

${ }^{81}$ Szwajcarski teolog Hans Küng jest autorem książki Der globale Ethos, w której poszukuje wspólnej aksjologicznej i etycznej podstawy dla różnych kultur, religii, światopoglądów i dla tych, którzy nie identyfikują się z żadną tradycją.
} 
wartości." ${ }^{\$ 2}$ Każdemu można powiedzieć, że tylko to będzie miało sens, za co weźmie odpowiedzialność. Analiza egzystencji widzi człowieka jako istotę zorientowaną na sens i dążącą do wartości, w przeciwieństwie do psychoanalitycznego ujęcia człowieka, jako istoty w pierwszej linii zdeterminowanej przez popędy i dążenie do przyjemności. „Ludzkie bycie jest byciem odpowiedzialnym, ponieważ jest byciem wolnym." ${ }^{83}$ Wolność i odpowiedzialność są zrozumiałe same przez się. Nie potrzebują żadnego uzasadnienia ani wyjaśnienia przez coś innego.

Człowiek jako wolny, jest istotą decydującą w sposób wolny - w ten sposób znowu oddalamy się od powszechnej egzystencjalistycznej koncepcji czystej wolności - ponieważ w byciu wolnym nie zawiera się jeszcze żadne Po co wolności - podczas gdy w decydowaniu zdaje się być już dane to Po co i Przeciw czemu decydowania: obiektywny świat sensu i wartości, a mianowicie ten świat, jako uporządkowany świat, to znaczy, kosmos $^{84}$.

W Starożytności greckiej kosmos był jednością bycia duchowego (kosmos noetos) i bycia materialnego (kosmos aisthetos). W analizie egzystencji kosmos bycia ludzkiego jednoczy się z kosmosem, zbudowanym z sensu i wartości. Wolność bez odpowiedzialności jest bez sensu. Odpowiedzialność nie jest ograniczeniem wolności, lecz możliwością jej wypełnienia. Sensem wolności jest odpowiedzialność.

Analiza egzystencji określa wartości jako relatywne pod dwoma względami. Wartości występują w relacji do człowieka, który je urzeczywistnia i do sytuacji, którą napotka. Wartości są też w inny sposób relatywne: występują w relacji do jednej wartości, „która jest miarą i podstawą wszelkiego ludzkiego wartościowania" ${ }^{" 5}$. Coś wartościowego może wyrosnąć z wartościowego podłoża. Wartość, która jest punktem odniesienia dla innych wartości, nie jest, przez stopniowanie, wartością najwyższą, jako ukoronowanie hierarchii wartości. W wartości podstawowej inne wartości znajdują swoje ugruntowanie. Bycie wartości podstawowej różni się istotnie od bycia innych wartości. Różnica między wartością podstawową i innymi wartościami jest

\footnotetext{
${ }^{82}$ V. E. Frankl, Logotherapie und Existenzanalyse, s. 98.

${ }^{83}$ V. E. Frankl, Ärztliche Seelsorge, s. 130.

${ }^{84}$ V. E. Frankl, Logotherapie und Existenzanalyse, s. 100.

${ }^{85}$ V. E. Frankl, Homo patiens, Verlag Deuticke, Wien 1950, s. 86.
} 
różnicą aksjologiczną ${ }^{86}$. „Tylko od absolutnej wartości można w ogóle wartościować. U podstaw każdego wartościowania leży maksymalna wartość, optymalna wartość. Dopiero od niej rzeczy otrzymują swoją wartość." ${ }^{87}$ Według logiki „myśliciela myślącego do końca” ${ }^{88}$ Frankl daje na innym miejscu do zrozumienia, co pojmuje przez „maksymalną wartość”: „Dopiero od absolutnej wartości, od absolutnej osoby wartości: od Boga - rzeczy otrzymują wartośćn" ${ }^{\prime 9}$. To, co wartościowe odzwierdziedla Boskość w świecie. Świat zyskuje na wartości przez to, co Boskie. Sens, przekazywany przez wartości, jawi się nam jak światło, które wychodzi od tego, co Absolutne i załamuje się w rzeczach świata. Jeżeli rzeczy są wartościowe ze względu na Boga jako absolutną wartość, to poszukiwanie sensu przez urzeczywistnianie wartości nabiera ponadświatowego wymiaru.

\section{Bibliografia}

\section{Dzieła V. E. Frankla}

Frankl V. E., Logotherapie und Existenzanalyse. Texte aus sechs Jahrzehnten, Beltz Verlag, Weinheim und Basel 2010.

Frankl V. E., Ärztliche Seelsorge. Grundlagen der Logotherapie und Existenzanalyse. Mit den „Zehn Thesen die über die Person“, Deutscher Taschenbuch Verlag, München 2015.

\footnotetext{
${ }^{86}$ Różnicę między byciem a tym, co bytuje nazywa Heidegger różnicą ontologiczną. Natomiast różnicę między byciem a Bogiem nazywa różnicą teologiczną.

${ }^{87}$ V. E. Frankl, Der leidende Mensch, s. 223.

${ }^{88}$ V. E. Frankl, Die Sinnfrage in der Psychotherapie, s. 146.

${ }^{89}$ V. E. Frankl, Der leidende Mensch, s. 223. Alfried Längle, uczeń Frankla, który w swojej psychoterapii uwględnia pytanie o Boga, uważa, że Frankl w sposób nieuzasadniony wprowadza do swojej teorii pojęcie Boga. Twierdzi, że pytanie o Boga w terapii powinno być otwarte i pozostawione wyborowi i decyzji pacjenta. A. Längle, Zur ontologischen und existentiellen Bestimmung von Sinn. Analyse und Weiterführung des logotherapeutischen Sinnverständnisses, [w:] Sinnverlust und Sinnfindung in Gesundheit und Krankheit, Hrsg. von H. Csef, Königshausen \& Neumann Verlag, Würzburg 1998, s. 256. Trudno zrozumieć Länglego. Frankl rozróżnia między logoterapią a analizą egzystencji. Logoterapia, jako terapia sensem, nie zakłada żadnego pojęcia Boga, aby pozostać światopoglądowo i wyznaniowo neutralną wobec chorych na nerwicę, o różnym wyznaniu i światopoglądzie lub ich braku. Analiza egzystencji natomiast rozjaśnia filozoficznie możliwości egzystencji w wypełnieniu sensu przez urzeczywistnienie wartości, które metafizycznie są ugruntowane w Bogu.
} 
Frankl V. E., ... trotzdem ja zum Leben sagen. Ein Psychologe erlebt das Konzentrationslager, Kösel Verlag, München 2009.

Frankl V. E., Die Psychotherapie in der Praxis. Eine kasuistische Einführung für Ärzte, Piper Verlag, München 1997.

Frankl V. E., Der unbewußte Gott. Psychotherapie und Religion, Deutscher Taschenbuch Verlag, München 2017.

Frankl V. E., Theorie und Therapie der Neurosen. Einführung in Logotherapie und Existenzanalyse, Ernst Reinhardt Verlag, München - Basel 2007.

Frankl V. E., Der Wille zum Sinn. Ausgewählte Vorträge über Logotherapie, Hans Huber Verlag, Bern 2005.

Frankl V. E., Der leidende Mensch. Anthropologische Grundlagen der Psychotherapie, Hans Huber Verlag, Bern 2005.

Frankl V. E., Das Leiden am sinnlosen Leben. Psychotherapie für heute, Herder Verlag, Freiburg im Breisgau 2009.

Frankl V. E., Der Mensch vor der Frage nach dem Sinn. Eine Auswahl aus dem Gesamtwerk, Piper Verlag, München 2009.

Frankl V. E., Die Sinnfrage in der Psychotherapie, Piper Verlag 1997.

Frankl V. E., Was nicht in meinen Büchern steht. Lebenserinnerungen, Beltz Verlag, Weinheim 2002.

Frankl V. E., Bergerlebnis und Sinnerfahrung, Tyrolia Verlag, Innsbruck - Wien 2008.

Frankl V. E., Lapide P., Gottessuche und Sinnfrage, Gütersloher Verlagshaus, Gütersloh 2007.

Frankl V. E., Die Psychotherapie für den Alltag, Franz Deuticke Verlag, Wien 1982.

Frankl V. E., Im Anfang war der Sinn, Franz Deuticke Verlag, Wien 1982.

\section{Opracowania}

Böschemeyer U., Die Sinnfrage in Psychotherapie und Theologie. Die Existenzanalyse und Logotherapie Viktor Frankls aus der theologischen Sicht, De Gruyter Verlag, Berlin 1977.

Längle A., Viktor Frankl - eine Begegnung, Facultas Verlags- und Buchandels AG, Wien 2013.

Längle A., Sinnvoll leben. Eine praktische Anleitung der Logotherapie, Residenz Verlag, St. Pölten Salzburg 2007.

Psychotherapie in Darstellungen, L. J Pongratz (hrsg.), Hans Huber Verlag, Bern Stuttgart - Wien 1973.

Raskob H., Die Existenzanalyse und Logotherapie Frankls, Springer Verlag, München 2006.

Viktor Frankl und die Philosophie, D. Battyany, O. Zsok (hrsg.), Springer Verlag, Wien - New York 2005. 
Lukas E., Lehrbuch der Logotherapie. Menschenbild und Methoden, Profil Verlag, München 2006.

Lukas E., Der Schüssel zu einem sinnvollen Leben, Kösel - Verlag, München 2011.

Sinnverlust und Sinnfindung in Gesundheit und Krankheit, H. Csef (hrsg.), Königshausen \& Neumann Verlag, Würzburg 1998.

Fabry J., Wege zur Selbstfindung: wie man jedem Tag seinen Sinn gibt, Herder Verlag, Freiburg im Breisgau Basel Wien 1985.

Fabry J., Das Ringen um Sinn, Paracelsus Verlag, Stuttgart 1973.

\section{Abstract \\ Searching for Meaning in Viktor Frankl's Logotherapy and Existential Analysis}

The starting from the psychoanalysis of Sigmund Freud and Individual Psychology of Alfred Adler, Viktor Frankl (1905-1997) developed an independent approach, which he called "Logotherapy and Existential Analysis". Logotherapy and Existence Analysis is a clinically underpinned, meaning-oriented psychotherapeutic procedure. The aim of that procedure is a confrontation of the human being with the question of the meaning of his existence and the accompanying the patient in finding concrete possibilities of meaning. Logotherapy provides help in recovering the meaning of one's life. Frankl distinguishes between three meanings of the meaning: the meaning in life (meaning of the situation), the meaning of life as a whole, and the meaning of the world (over-meaning). The meaning in life can be found mainly in the situation. The meaning of life $s$ a whole consists of the meaning of the situations, which the human being has meaningfully experienced, by the realization of the values. The meaning of the situation presupposes the over-meaning. The over-meaning is outside of the possibilities of knowledge. You can only believe in him.

Keywords: Frankl, logotherapy, existential analysis, meaning, values, situation, person, freedom, spirit, neurosis, responsibility 